\title{
Study on the Application of Problem - solving Method in Community Service in Higher Vocational Education
}

\author{
Wen-Ying $\mathrm{XU}^{1}$ a , Jian-Qing $M A^{*}, 2, \mathrm{~b}$ \\ ${ }^{1}$ School of Marxism, Zhejiang University, Hangzhou, China \\ 2 School of accounting and finance, Zhejiang Business College, Hangzhou, China \\ aemail: helen.0013@163.com, bemail: majq2007@163.com \\ *Corresponding author
}

Keywords: Community service, Problem solving method, Social service.

\begin{abstract}
At present, talent training, scientific research, social service as the three functions of the university are recognized by scholars at home and abroad. Community as one of the important part of society, the university's community service function has been recognized in more and more areas. However, the community service still exists consciousness of initiative service is not strong, emotional connection is not deep, service effect is difficult to continue, and so on. Problem Solving Method is a kind of problem-centered teaching method by which students acquire knowledge and skills through the process of finding out problems, analyzing problems and solving the problems. Based on this, this paper takes Problem Solving Method as an attempt, describes in detail the process of the problem solving method applied to the community service function of higher vocational .The paper points out that we can apply problem solving method in teaching, practice, graduation design. Specifically, the following steps can be referred to: do early research, develop the projects according to demands of community, associate with teaching, analysis the problems, formulate the problem solution, evaluate and adjust and so on. Then to overcome the difficulties, integrate resources, and then further improve the quality of community service quality, improve the effectiveness of teaching and research in higher vocational colleges.
\end{abstract}

\section{Introduction}

Talent training, scientific research, social services are known as the three major functions of the University. The social services function of university refers to provide direct service activities to society (Chang Liu, 2013).Nowadays, more and more social responsibility education promotes the integration of college students and the social environment(Qi li, Jiaoxiong Xia \& Jun Xu,2008). It can be seen that the social service function of university has important practical significance to the society and university. Therefore, university must also work hard in their social service functions. Especially for the higher vocational colleges which focus on the cultivation of applied talents for the society, it is a good exploration to explore the effective ways of community service which can be benefit for reflecting the characteristics and value.

\section{Problems in Social Service in University}

The social service function of university in China has been developing about 30 years since the concept was put forward (Rui Huang, 2015). With the development of the social service in university, the social service of university has made great progress in practice, but there are still some problems. As the most basic content of social organism ---- community, community service is one of an important part of social service .So we take community service as an example to discuss the problems of social service from university. 


\section{Consciousness of Community Service is not Strong}

At present, due to the current assessment of the education system, the breadth and depth of the understanding of community services in some universities need to be improved. At present, the evaluation of universities by the state education authorities is mainly limited to the evaluation of talent training, teaching level, scientific research level and the basic conditions of running schools (Tongwen $\mathrm{Xu}, 2004)$. All these leads to the service tradition consciousness is not strong, the service behavior level is also not in-depth, but also failed to form a specific service assessment indicators and assessment.

\section{Emotional Ties in Community Service are not Close}

At present, there are many forms of community services, such as social practice, volunteer service, lectures, individual project services, old age education, and so on. The service object and the contact object are also changing, failing to form a normal mechanism. The community also lacks the awareness and methods of teaching. Students are not involved deeply in the community service. They are not closely connected with the teaching during the service. Students are often in the situation of lack of teaching. Therefore, it is difficult to establish and deepen the emotional connection.

\section{The Effect of Community Services is Difficult to Maintain}

The community arranges the university community service in the community neighborhood committee, the community welfare organization and so on, it has not been able to go deep into the common life, and the practical resource is relatively simple. Under normal circumstances, the community has not specifically set the corresponding implementation of community service of university. In addition, the interaction between universities and the community lacks the necessary legal environment protection. In the western universities and community interaction are protected by law; universities lack the necessary specialized agencies responsible for community affairs (Yuanyuan Yuan, 2006). These led to the quality of community service is not high, the effect is difficult to continue. So it is an important content for university to establish the linkage with the community, to expand the community service and to improve the teaching effect.

\section{The Application of Project - Based Problem Solving Method in Community Service in University}

The problem solving method as a new teaching method, it is different from the traditional teaching, it pays more attention on cultivating students' ability to solve problems. Its application in community service which can be more closely linked with the actual teaching and be more helpful to provide the better service the community.

The problem-solving method is applied to the community service, which mainly refers to the combination of teaching and concrete community service. It takes the needs of the community, the problems existing in the community life as the direction, designs the projects. It provides diverse modes to help students to learn, master certain skills and promote the comprehensive abilities.

Specifically, the application of problem solving method to the community service should do the following work:

\section{Preliminary Investigation}

According to the American progressive educator, "school is the basic form of the community; the school is the epitome of community life". The university cannot complete its goal of education alone (Zhixin Su, 1995). The educated object must practice, live and grow in the community in order to get proper education results. The community as a small society, it contains a lot of dominant, recessive resources which can be used as teaching materials and teaching situation, so 
that students will learn better in their major. Therefore, in the early stage, through a variety of ways of research, collect the problems and needs closely linked to life; explore the possibility of being a teaching project.

\section{A Problem-Oriented Project}

Based on the analysis of the previous research, select the project, and further clarify the objectives of the project, tasks for teaching. These projects can be representative of the real needs, problems, or it can be re-designed according to teaching requirements. On the one hand, it is easy to be recognized by students; on the other hand, it can provide a clear direction for practical teaching, so as to enhance teaching pertinence. At the time of design, understanding the problem, analyzing the problem and solving the problem is a whole process, so learning is not only a continuous process, but also a practical problem-solving. In this process, the design of a reasonable problem situation, the use of problem setting to allow students to understand the problem, analyze and solve problems which help students to participate actively, more innovative and more cooperative.

For example: To investigate the air conditioning common problems in community, then divide the research results into some categories for air-conditioning refrigeration, air conditioning maintenance-related courses. And more, response to community advocacy of energy-saving emission reduction, to investigate the actual use of electricity, design sound and light transformation of the switch and other projects.

\section{Associate Teaching}

The problem-solving method can provide the opportunity to develop comprehensive skills, such as high-level thinking ability, problem solving ability, cooperation and communication ability. The application of problem-solving method to community service, the requirements of the project is relatively high, requires the project should relate to the teaching ,the implementation of the project must also be dispersed into teaching knowledge, skills, teaching tasks, students complete the tasks step by step according to the project mission. By linking the actual problems, students operate and internalization, so the teaching effect will be better than before.

For example: As for the community residents' love for electronic photo albums, the short video, students majoring in media produce can the involved in the projects related to electronic photo album, short video production. In this way, students can get a better understanding of the function of different software.

\section{Implementation of the Problem-Solving Method}

The first step in using problem-solving method is all students need to explore, comb problem-related information, further clarify the problem, find out the direction of problem-solving, then evaluate the best problem solution. With the solution of the problem, it can mobilize more people to participate, develop students' self-confidence and improve their attitude towards learning. In this process, the teachers should guide students to think: What happened? What are the causes? How to obtain the relevant material? How to solve the problem? ... ... to enable students to solve problems around the problem through the discussion, to collect relevant information to identify information and problems associated with the solution and report, then check the final solution under the guidance of the teacher.

For example: Due to the poor performance, a handmade chocolate shop in the community needs some help to improve matters .We can throw this problem to the students majoring in marketing. So that they can use the knowledge to further clarify the problem, then based on it, help the store to do product positioning, design packaging and make the promotional strategies, at last solve the problem. In this process, students will be able to master the process of identifying opportunities, developing new products, and attracting customers by solving problems. 


\section{Conclusion}

In conclusion, in view of the important significance of social service for the universities and society, it is meaningful to explore effective interaction between university and community. The application of problem solving method will be an effective application to change the university community service tradition. It integrates teaching, scientific research and community service effectively. It not only improves the effectiveness of teaching and research, improve the quality of student training, but also an important way of social services by university.

\section{References}

[1] Chang Liu, The basic features of social service functions of regional college ,Heilongjiang Researches on Higher Education.2013

[2] Rui Huang, Development and Realization of College of Social Service Function, Management and Administration.2015

[3] Qi Li, Thinking on the interaction between university students' living area and residents' community, Journal of Shanghai University.2008

[4] Jingyun Shao, Research on the role and function of College Students' associations in the community work in Colleges, Northwest Agriculture and Forestry University.2014

[5] Yuan Yuanyuan, The theory and practice of the interaction between colleges and communities, Shanghai Normal University. 2006

[6] Bin Li, “Problem solving” Method in Teaching, Ideological Education Research. 2004

[7] Xi-hong $\mathrm{Xu}$, The cultivation of students' autonomous learning ability under the mode of “problem solving”, Academic Weekly. 2016

[8] Weixin Yuan, The definition, process and teaching mode of problem solving, Psychological Science.2010 